\title{
Antiplatelet effects of scoparone through up-regulation of cAMP and cGMP on U46619-induced human platelets
}

\author{
Dong-Ha Lee L,2 $^{1,2}$
}

Received: 10 October 2019 / Accepted: 14 November 2019 / Published Online: 31 December 2019

(C) The Korean Society for Applied Biological Chemistry 2019

\begin{abstract}
Platelet activation is essential for hemostatic process on blood vessel damage. However, excessive platelet activation can cause some cardiovascular diseases including atherosclerosis, thrombosis, and myocardial infarction. Scoparone is commonly encountered in the roots of genus Artemisia or Scopolia, and has been studied for its potential pharmacological properties including immunosuppression and vasorelaxation, but antiplatelet effects of scoparone have not been reported yet. We investigated the effect of scoparone on human platelet activation prompted by an analogue of thromboxane $\mathrm{A}_{2}, \mathrm{U} 46619$. As the results, scoparone dose-dependently increased cyclic adenosine monophosphate (cAMP) levels as well as cyclic guanosine monophosphate (cGMP) levels, both being aggregation-inhibiting molecules. In addition, scoparone strongly phosphorylated inositol 1, 4, 5triphosphate receptor $\left(\mathrm{IP}_{3} \mathrm{R}\right)$ and vasodilator-stimulated phosphoprotein (VASP), substrates of cAMP dependent kinase and cGMP dependent kinase. Phosphorylation of $\mathrm{IP}_{3} \mathrm{R}$ by scoparone resulted in inhibition of $\mathrm{Ca}^{2+}$ mobilization in calcium channels in a dense tubular system, and phosphorylation of VASP by scoparone led to an inability of fibrinogen being able to bind to $\alpha \mathrm{IIb} / \beta 3$. Finally, scoparone inhibited thrombin-induced fibrin clotting, thereby reducing thrombus formation. Therefore, we suggest that scoparone has a strong antiplatelet effect and is highly probable to prevent platelet-derived vascular disease.
\end{abstract}

Dong-Ha Lee $(\triangle)$

E-mail:dhlee@nsu.ac.kr

${ }^{1}$ Department of Biomedical Laboratory Science, Namseoul University, Cheonan 31020, Republic of Korea

${ }^{2}$ Molecular Diagnostics Research Institute, Namseoul University, Cheonan 31020 , Republic of Korea

This is an Open Access article distributed under the terms of the Creative Commons Attribution Non-Commercial License (http://creativecommons. org/licenses/by-nc/3.0/) which permits unrestricted non-commercial use, distribution, and reproduction in any medium, provided the original work is properly cited.
Keywords Cyclic adenosine monophosphate/Cyclic guanosine monophosphate $\cdot$ Fibrinogen binding · Inositol 1, 4, 5-triphosphate receptor · Intracellular $\mathrm{Ca}^{2+} \cdot$ Scoparone $\cdot$ Vasodilator-stimulated phosphoprotein

\section{Introduction}

Platelet aggregation is an essential response to the formation of hemostatic plug when blood vessels are damaged. In particular, the concentration of $\mathrm{Ca}^{2+}\left(\left[\mathrm{Ca}^{2+}\right]_{\mathrm{i}}\right)$ in the cytoplasm of platelets plays a key role in the activation of platelet aggregation. $\left[\mathrm{Ca}^{2+}\right]_{i}$ is known to be recruited into the cytoplasm through the receptors from the dense tubular system, an internal reservoir, by inositol 1, 4, 5-triphosphate $\left(\mathrm{IP}_{3}\right)$ [1]. Increased $\left[\mathrm{Ca}^{2+}\right]_{\mathrm{i}}$ phosphorylates myosin light chain $(20 \mathrm{kDa})$, which is dependent on the $\mathrm{Ca}^{2+} /$ calmodulin complex, and phosphorylates pleckstrin by activating protein kinase $\mathrm{C}$ in cooperation with diacylglycerol (DG). This leads to rearrangement of cytoskeletal proteins and finally to platelet aggregation [1].

In addition, DG, which is produced by the breakdown of phosphatidylinositol 4,5-bisphosphate $\left(\mathrm{PIP}_{2}\right)$ located on the platelet membrane, is sequentially hydrolyzed by DG lipase and monoacyglycerol lipase and converted to Thromboxane $\mathrm{A}_{2}$ $\left(\mathrm{TXA}_{2}\right)$ via arachidonic acid [2]. TXA 2 is known to activate platelets to induce secretion and morphological changes [3]. Indeed, U46619 (9,11-dideoxy-9a.la-methanoepoxyprostaglandin F2a), a stable analogue of $\mathrm{TXA}_{2}$, is used as a proper platelet aggregation inducer to increase phosphorylation of the myosin light chain and pleckstrin by increasing $\left[\mathrm{Ca}^{2+}\right]_{i}[4,5]$. This is a normal process of hemostatic reactions in the blood but can also cause various vascular diseases such as atherosclerosis when excessive platelet aggregation occurs. Thus, adequately inhibiting platelet aggregation may be a useful approach to prevent cardiovascular disease [4,5]. 
Verapamil and theophylline function as antiplatelets by increasing levels of cyclic adenosine monophosphate (cAMP), which reduces $\left[\mathrm{Ca}^{2+}\right]_{\mathrm{i}}$, an essential component of platelet aggregation. In addition, guanosine monophosphate (cGMP) levels in platelets are increased with the use of cyclic cGMP phosphodiesterase (PDE) inhibitors like erythro-9- (2-hydroxy-3-nonyl) adenine and zaprinast, or vasodilators such as molsidomine and nitroprusside [6]. During normal circulation, vascular endothelial cells release nitric oxide and prostaglandin $\mathrm{I}_{2}$, which causes the platelets to produce cyclic adenosine monophosphate (cAMP) and cyclic cGMP. Elevated cAMP levels induce activation of protein kinase A (PKA) while elevated cGMP levels lead to the activation of protein kinase $G$ (PKG). Together, PKA and PKG phosphorylate substrate protein inositol 1, 4, 5-triphosphate receptor $\left(\mathrm{IP}_{3} \mathrm{R}\right)$ and vasodilatorstimulated phosphoprotein (VASP) [7]. Phosphorylation renders $\mathrm{IP}_{3} \mathrm{R}$ inactive, causing mobilization of $\left[\mathrm{Ca}^{2+}\right]_{\mathrm{i}}$ to become inhibited $[8,9]$. In the platelet, vasodilator-stimulated phosphoprotein is a major substrate of PKA and PKG and it contributes to activation of $\alpha \mathrm{IIb} / \beta_{3}$ as well as the regulation of actin filament dynamics. However, suppression of $\alpha \mathrm{II} b / \beta_{3}$ activation and inhibition of actin filament elongation can be caused through cAMP-dependent VASP Ser ${ }^{157}$ phosphorylation or cGMP-dependent VASP Ser239 phosphorylation $[10,11]$. As a result, phosphorylation of $\mathrm{IP}_{3} \mathrm{R}$ can be very helpful when investigating the $\mathrm{Ca}^{2+}$-antagonistic effect, whereas VASP phosphorylation is essential for evaluating $\alpha \mathrm{IIb} / \beta_{3^{-}}$ inhibition effect.

Scoparone, commonly found in the roots of plants of the genus Scopolia or Artemisia, has been studied for its potential pharmacological properties including immunosuppression and vasorelaxation $[12,13]$. However, the role of scoparone in platelet activation and the mechanism of scoparone on human platelet aggregation caused by U46619 is unknown. This study examined the effect of scoparone on various factors related to U46619induced platelet activation to clarify the antiplatelet effects of scoparone.

\section{Materials and Methods}

\section{Materials}

Scoparone (6,7-Dimethoxy-2H-chromen-2-one) was purchased from Avention Corporation (Seoul, Korea) (Fig. 1). Chrono-Log Corporation (Havertown, PA, USA) provided U46619. Both cAMP and cGMP enzyme immunoassay (EIA) kits were received from Cayman Chemical (Ann Arbor, MI, USA). Fura 2-AM and Fibrinogen Alexa Fluor 488 conjugates were purchased from Invitrogen (Eugene, OR, USA). Anti-VASP, anti-phosphor-VASP $\mathrm{Ser}^{239}$, anti-phosphor-VASP Ser ${ }^{157}$, anti-phosphor-inositol-3phosphate receptor type I, the lysis buffer, anti-rabbit IgG-HRPconjugate, and anti- $\beta$-actin were obtained from Cell Signaling (Beverly, MA, USA). Enhanced chemiluminescence solution (ECL) and polyvinylidene difluoride (PVDF) membrane were purchased from General Electric Healthcare (Chalfont St. Giles, Buckinghamshire, UK). The Fibrinogen Alexa Fluor 488 conjugate was obtained through Invitrogen Molecular Probes (Eugene, OR, USA).
(A)<smiles>COc1cc2ccc(=O)oc2cc1OC</smiles>

(B)

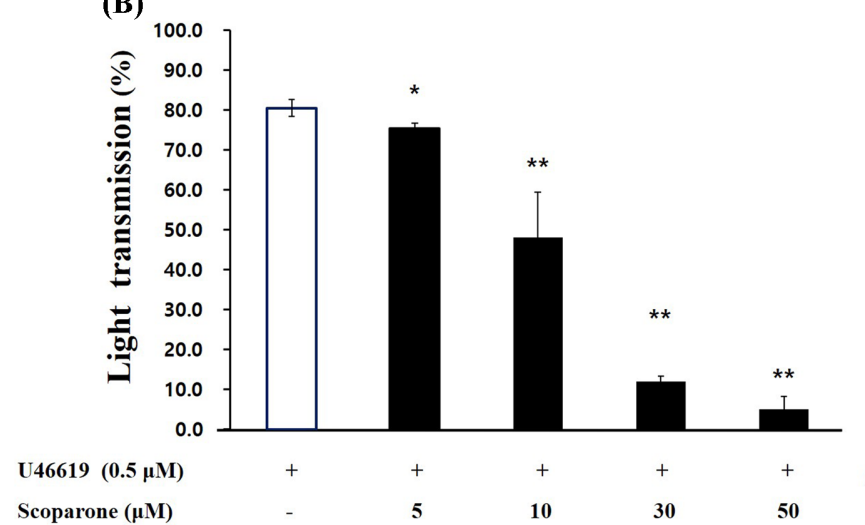

(C)

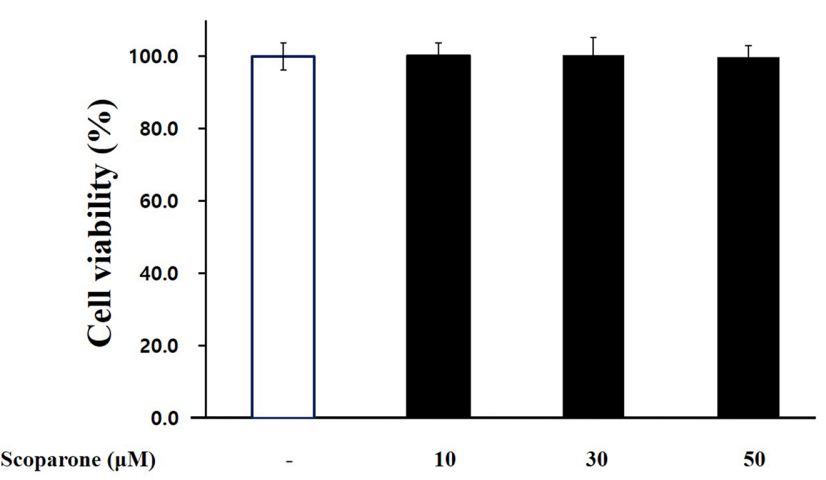

Fig. 1 The structure of scoparone and the effects of scoparone on U46619-induced platelet aggregation. (A) Chemical structure of scoparone. PIN: 6,7Dimethoxy-2H-chromen-2-one, Chemical formula: $\mathrm{C}_{11} \mathrm{H}_{10} \mathrm{O}_{4}$, Molar mass: $206.19 \mathrm{~g} / \mathrm{moL}$. (B) Effects of scoparone pretreatment on U46619-stimulated platelet aggregation. (C) Cytotoxicity of scoparone on human platelets. Washed platelets $\left(10^{8} / \mathrm{mL}\right)$ were preincubated with various concentrations of scoparone in the presence of $2 \mathrm{mM} \mathrm{CaCl}_{2}$ for $3 \mathrm{~min}$ at $37{ }^{\circ} \mathrm{C}$, then stimulated with $\mathrm{U} 46619(0.5 \mu \mathrm{M})$ for $5 \mathrm{~min}$. Platelet aggregation (\%) was recorded as an increase in light transmission. The data are expressed as the mean \pm standard deviation $(\mathrm{n}=4)$. ${ }^{*} p<0.05, * * p<0.001$ compared with the U46619stimulated platelets 


\section{Preparation of washed human platelets}

Korean Red Cross Blood Center (Suwon, Korea) provided human platelet rich plasma (PRP). Washed platelets were prepared according to the previously published method [14]. PRP was centrifuged for $10 \mathrm{~min}$ at $1,300 \times \mathrm{g}$ to obtain platelets, which were washed twice with wash buffer $(138 \mathrm{mM} \mathrm{NaCl}, 2.7 \mathrm{mM} \mathrm{KCl}, 12$ $\mathrm{mM} \mathrm{NaHCO} 3,0.36 \mathrm{mM} \mathrm{NaH} \mathrm{PO}_{4}, 5.5 \mathrm{mM}$ glucose, and $1 \mathrm{mM}$ $\mathrm{Na}_{2}$ EDTA, pH 6.9). A suspension buffer (138 mM NaCl, $2.7 \mathrm{mM}$ $\mathrm{KCl}, 12 \mathrm{mM} \mathrm{NaHCO}, 0.36 \mathrm{mM} \mathrm{NaH}_{2} \mathrm{PO}_{4}, 0.49 \mathrm{mM} \mathrm{MgCl}_{2}, 5.5$ $\mathrm{mM}$ glucose, $0.25 \%$ gelatin, $\mathrm{pH} 7.4$ ) at a final concentration of $10^{8} / \mathrm{mL}$ was used to suspended the washed platelets. All procedures were performed at $25^{\circ} \mathrm{C}$. to avoid platelet aggregation at low temperatures. This experiment was performed and executed with the approval of the Institutional Review Board of Namseoul University (1041479-HR-201803-003).

\section{Platelet aggregation}

Platelets $\left(10^{8}\right.$ cells $\left./ \mathrm{mL}\right)$ were preincubated in separate samples with or without scoparone in $2 \mathrm{mM} \mathrm{CaCl}_{2}$ for $3 \mathrm{~min}$ at $37^{\circ} \mathrm{C}$, and $\mathrm{U} 46619(0.5 \mu \mathrm{M})$ was then added to stimulate. An aggregometer was used for $5 \mathrm{~min}$ to perform the platelet aggregation assay. An increase in light transmission was used to determine the platelet aggregation rate $(\%)$.

\section{Measurement of cytotoxicity}

Cytotoxicity was determined through the leakage of lactate dehydrogenase (LDH) from cytosol. Human washed platelets $\left(10^{8}\right.$ cells $/ \mathrm{mL}$ ) were incubated for 2 hours at room temperature with various concentrations of substances and then centrifuged at room temperature for $2 \mathrm{~min}$ at $12,000 \mathrm{~g}$. The supernatant was measured by LDH assay kit at an optical density of $490 \mathrm{~nm}$.

\section{Intracellular calcium concentration}

For $60 \mathrm{~min}$, PRP was incubated at $37^{\circ} \mathrm{C}$ with $5 \mu \mathrm{M}$ of Fura 2AM. Fura 2-AM is sensitive to light, so aluminum foil was used to cover the tube containing PRP. Washed platelets $\left(10^{8}\right.$ cells $\left./ \mathrm{mL}\right)$ filled with Fura 2 were prepared using the procedure specified above, incubated at $37{ }^{\circ} \mathrm{C}$ together with $2 \mathrm{mM} \mathrm{CaCl}_{2}$ for $3 \mathrm{~min}$, and then treated for $5 \mathrm{~min}$ by treatment with U46619 $(0.5 \mu \mathrm{M})$. The fluorescence of Fura 2 was measured using a spectrophotometer (SFM 25, BioTeck Instrument, Legnano, Italy). The excitation wavelength was initially set at $340 \mathrm{~nm}$ and increased at increments of $0.5 \mathrm{~s}$ ultimately reaching $380 \mathrm{~nm}$. A wavelength setting of $510 \mathrm{~nm}$ was used for the emission wavelength. The calculations of $\left[\mathrm{Ca}^{2+}\right]_{\mathrm{i}}$ values were performed using the Grynkiewicz method [15].

\section{Immunoblotting}

Platelet aggregation was terminated by addition of $1 \times$ lysis buffer. The resulting protein concentration of the platelet lysates was measured and evaluated using a BCA protein assay kit (Pierce Biotechnology, Rockford, IL, USA). Proteins (20 $\mu \mathrm{g})$ were
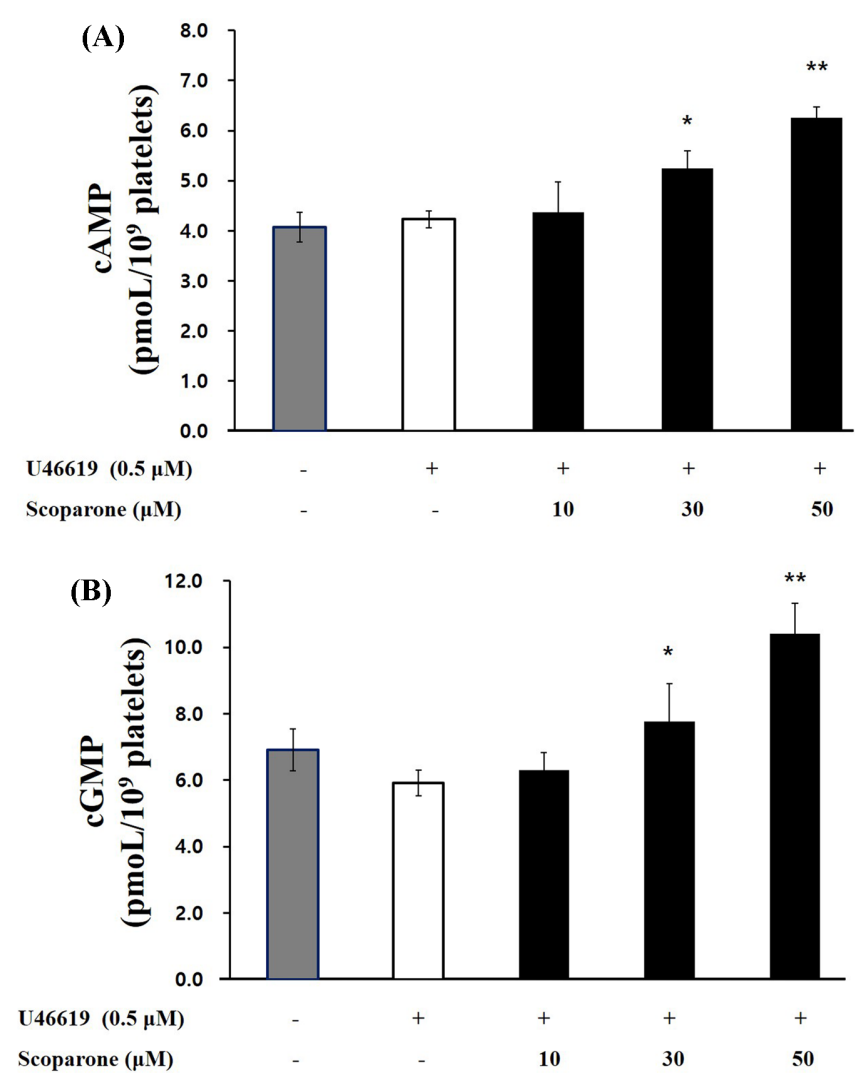

Fig. 2 Effects of scoparone on cyclic nucleotides production. (A) Effects of scopoletin on cAMP production stimulated by U46619. (B) Effects of scopoletin on cGMP production stimulated by U46619. Washed platelets $\left(10^{8} / \mathrm{mL}\right)$ were preincubated with or without scoparone for $3 \mathrm{~min}$ in the presence of $2 \mathrm{mM} \mathrm{CaCl}_{2}$ and then stimulated with $\mathrm{U} 46619(0.5 \mu \mathrm{M})$ for $5 \mathrm{~min}$ at $37^{\circ} \mathrm{C}$. The reactions were terminated by adding $1 \mathrm{M} \mathrm{HCl}$. cAMP and cGMP contents were measured using EIA kits. The data are expressed as the mean \pm standard deviation $(\mathrm{n}=4) .{ }^{*} p<0.05,{ }^{* *} p<0.001$ compared with the U46619-stimulated platelets

separated through 4-20\% SDS-PAGE, and relocated onto PVDF membranes. The primary antibodies were set at a dilution of $1: 1,000$ and the secondary antibodies were set at a dilution of 1:10,000. The protein bands were visualized using ECL reagent (General Electric Healthcare, Buckinghamshire, UK).

\section{Fibrinogen binding to $\alpha \mathrm{IIb} / \beta_{3}$}

Washed platelets $\left(10^{8}\right.$ cells $\left./ \mathrm{mL}\right)$ bound to Alexa Flour 488-human fibrinogen $(30 \mu \mathrm{g} / \mathrm{mL})$ were stimulated with U46619 $(0.5 \mu \mathrm{M})$ after adding $2 \mathrm{mM} \mathrm{CaCl}_{2}$. To terminate the reaction, phosphatebuffered saline (PBS, pH 7.4) containing 0.5\% paraformaldehyde was added. This process was performed while blocking the light, fibrinogen binding capacity was performed using a flow cytometer (BD Biosciences, San Jose, CA, USA) and analyzed by CellQuest software (BD Biosciences).

\section{Platelet-mediated fibrin clot retraction}

Human PRP $(500 \mu \mathrm{L})$ was moved into a polyethylene tube to 


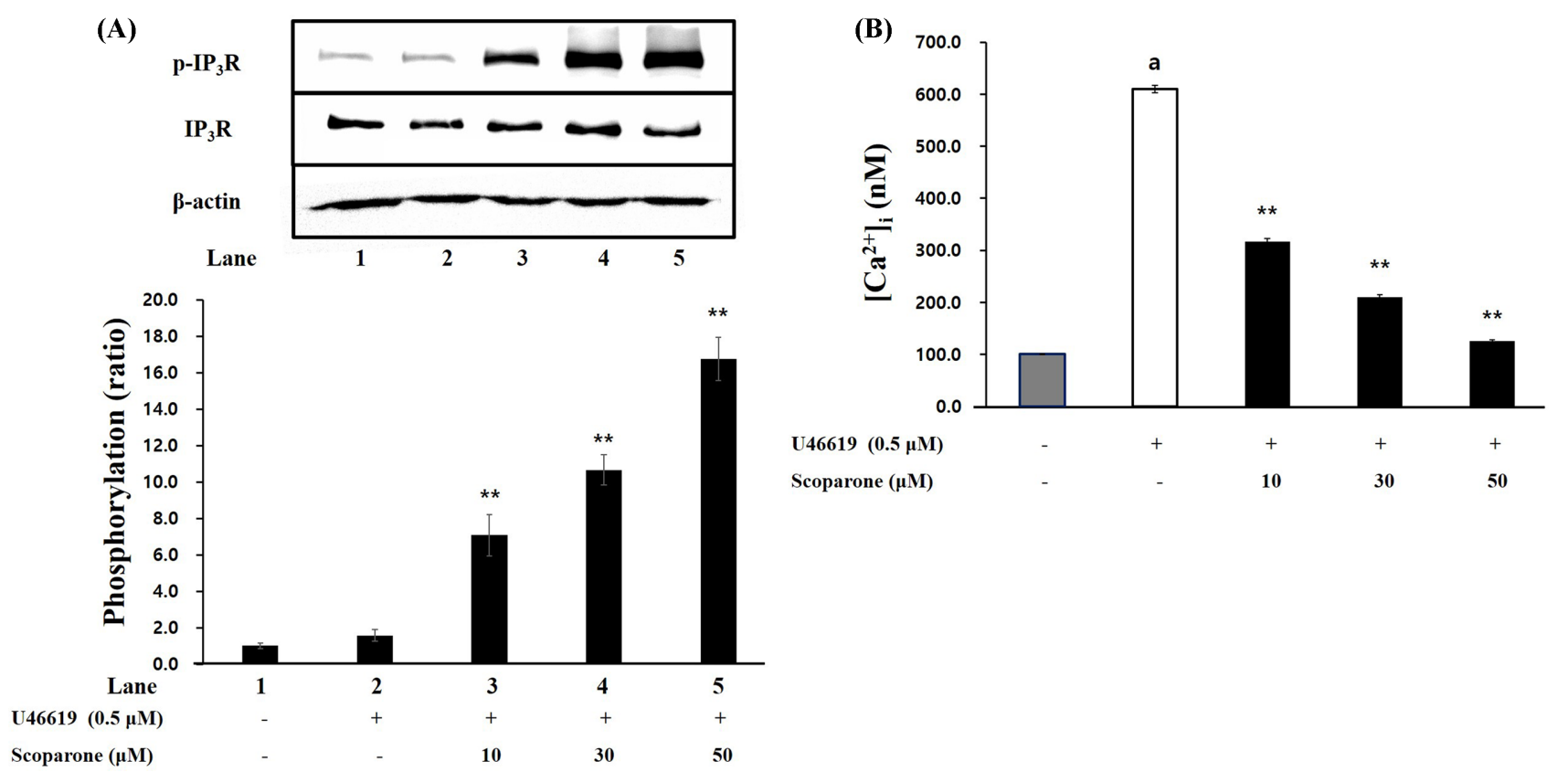

Fig. 3 Effects of scoparone on $\mathrm{IP}_{3} \mathrm{R}$ phosphorylation and $\left[\mathrm{Ca}^{2+}\right]_{\mathrm{i}}$ mobilization. (A) Effects of scoparone on U46619-induced $\mathrm{IP}_{3} \mathrm{R}$ phosphorylation. (B) Inhibitory effects of scoparone on U46619-induced $\left[\mathrm{Ca}^{2+}\right]_{\mathrm{i}}$ mobilization. Fura 2-filled washed platelets $\left(10^{8}\right.$ cells $\left./ \mathrm{mL}\right)$ were incubated at $37^{\circ} \mathrm{C}$ with 2 $\mathrm{mM} \mathrm{CaCl}_{2}$ for $3 \mathrm{~min}$, and then treated for $5 \mathrm{~min}$ with $\mathrm{U} 46619$ ( $\left.0.5 \mathrm{iM}\right)$. The fluorescence of Fura 2 was measured using a spectrophotometer (SFM 25, BioTeck Instrument, Italy). The excitation wavelength was initially set at $340 \mathrm{~nm}$ and increased at increments of $0.5 \mathrm{~s}$ ultimately reaching $380 \mathrm{~nm}$. A wavelength setting of $510 \mathrm{~nm}$ was used for the emission wavelength. The data are expressed as the mean \pm standard deviation $(\mathrm{n}=4)$. ${ }^{a} p<0.05$ compared with no-stimulated platelets, ${ }^{*} p<0.05,{ }^{* *} p<0.001$ compared with the U46619-stimulated platelets

avoid adhesion, various levels of scoparone $(10,30,50 \mu \mathrm{M})$ were preincubated with separate samples for $15 \mathrm{~min}$ at $37^{\circ} \mathrm{C}$, using thrombin $(0.05 \mathrm{U} / \mathrm{mL})$ for stimulation. At $15 \mathrm{~min}$, pictures of fibrin clot were taken using a digital camera. The area of the clot was calculated using the Image J Software (v1.46, National Institutes of Health, Bethesda, MD, USA).

\section{Statistical analyses}

Mean \pm standard deviation was used to express the experimental results, and statistical analysis was appropriately performed using either unpaired Student's t-test or ANOVA. Groups were compared by Scheffe's method if there were significant differences between group means according to ANOVA.

\section{Results}

Effects of scoparone on U46619-induced human platelet aggregation

$\mathrm{U} 46619$ at $0.5 \mu \mathrm{M}$ induces the optimum aggregation of human platelets, and in this study, U46619-induced platelets aggregation rate was $80.5 \%$ (Fig. 1B). However, platelets treated with scoparone $(5,10,30$, and $50 \mu \mathrm{M})$ had aggregation rates that were significantly reduced $(6.5,40.4,85.1$, and $93.8 \%$, respectively) without cytotoxicity (Fig. 1C), which indicates that scoparone inhibited U46619-induced platelet aggregation in a dose-dependent manner.

\section{Effects of scoparone on elevation of cAMP and cGMP}

We confirmed whether scoparone affects the production of cAMP or cGMP. As shown in Fig. 2A scoparone strongly increased cAMP production from $4.23 \pm 0.16$ to $6.26 \pm 0.21 \mathrm{pmoL} / 10^{8}$ cells. In addition, cGMP was significantly increased by scoparone from $5.92 \pm 0.38$ to $10.41 \pm 0.91 \mathrm{pmoL} / 10^{8}$ cells (Fig. $2 \mathrm{~B}$ ). These results indicate that scoparone functions in suppressing platelets activation by increasing the production of cAMP and cGMP in U46619-induced platelets.

\section{Effects of scoparone on elevation of $\left[\mathrm{Ca}^{2+}\right]_{i}$ mobilization, $\mathrm{IP}_{3} \mathrm{RI}$ phosphorylation}

Resulting from the fact that $\left[\mathrm{Ca}^{2+}\right]_{\mathrm{i}}$ is crucial for platelet activation, we examined the effect of scoparone on $\mathrm{Ca}^{2+}$ antagonistic activity. As shown in Fig. $3 \mathrm{~A},\left[\mathrm{Ca}^{2+}\right]_{\mathrm{i}}$ level was raised from $100.9 \pm 0.5 \mathrm{nM}$ to $609.5 \pm 7.2 \mathrm{nM}$ by U46619. However, scoparone dose (10 to 50 $\mu \mathrm{M}$ )-dependently decreased collagen-elevated $\left[\mathrm{Ca}^{2+}\right]_{\mathrm{i}}$ level (Fig. $3 \mathrm{~A})$. The inhibition rate of scoparone $(50 \mu \mathrm{M})$ was $79.5 \%$. Therefore, we expected that scoparone affects calcium mobilization and assessed the calcium mobilization signaling molecule and the effect of its phosphorylation. As shown in Fig. 3C, scoparone $(10$ to $50 \mu \mathrm{M})$ dose-dependently increased $\mathrm{IP}_{3} \mathrm{RI} \quad\left(\mathrm{Ser}^{1756}\right)$ phosphorylation in U46619-induced human platelet aggregation. This demonstrates that the decrease of intracellular calcium level by scoparone resulted from $\mathrm{IP}_{3} \mathrm{RI}\left(\mathrm{Ser}^{1756}\right)$ phosphorylation. 


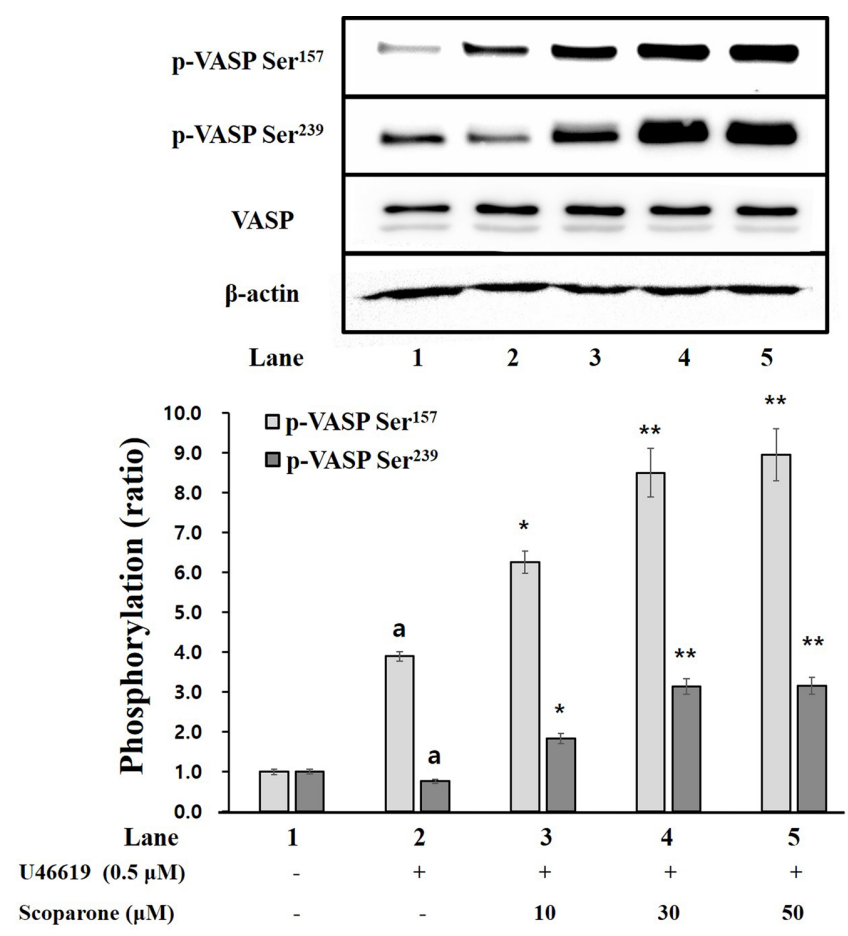

Fig. 4 Effects of scoparone on VASP phosphorylation. Immunoblotting was conducted to analyze the phosphorylation of signaling molecules extracted from the lysates of U46619-stimulated washed platelets that were pre-treated with scoparone. Representative immunoblot images and data $($ mean $\pm \mathrm{SD})$ are expressed as the mean \pm standard deviation $(n=4)$ ${ }^{a} p<0.05$ compared with no-stimulated platelets, ${ }^{*} p<0.05, * * p<0.001$ compared with the U46619-stimulated platelets

\section{Effects of scoparone on VASP-phosphorylation}

As scoparone showed a dose-dependent increasing effect on U46629-induced cAMP and cGMP level (Fig. 2), we further investigated the effect of scoparone on cAMP-dependent VASP Ser $^{157}$ phosphorylation and cGMP-dependent VASP $\operatorname{Ser}^{239}$ phosphorylation in U46619-activated platelets. Scoparone significantly increased VASP Ser ${ }^{157}$ and VASP Ser $^{239}$ phosphorylation (Fig. 4) in a dose-dependent manner.

\section{Effects of scoparone on fibrinogen binding to $\alpha \mathbf{I I b} / \beta_{3}$}

Since scoparone increased VASP Ser $^{157}$ phosphorylation and VASP $\operatorname{Ser}^{239}$ phosphorylation through elevation of cAMP and cGMP production (Fig.4), we investigated the effect of scoparone on fibrinogen binding to $\alpha \mathrm{IIb} / \beta_{3}$. U46619 increased the fibrinogen binding to $\alpha \mathrm{IIb} / \beta_{3}$ (Fig. 5A-b, 5B), with a rate of $91.7 \pm 1.0 \%$. However, fibrinogen binding was attenuated with the use of scoparone in a dose-dependent manner (Figs. 5A-c-f, 5B). The inhibition rate of scoparone $(50 \mu \mathrm{M})$ was $81.3 \%$.

\section{Effects of scoparone on fibrin clot retraction}

The binding of fibrinogen to $\alpha \mathrm{IIb} / \beta_{3}$ is increased by the activation of $\alpha \mathrm{IIb} / \beta_{3}$ through platelet agonists. In time, prompting the outside-in $\alpha \mathrm{IIb} / \beta_{3}$ signaling pathway as well as clot retraction.
Therefore, we investigated thrombin-induced fibrin clot retraction, an index of outside-in $\alpha \mathrm{IIb} / \beta_{3}$ signaling, in relation to the effect of scoparone. Fig. 6A displays both thrombin stimulated fibrin clot formation and clot retraction. Yet scoparone $(10,30$ and $50 \mu \mathrm{M})$ suppressed the thrombin-retracted fibrin clot, and these inhibitory degrees were $14.9,58.5$, and $92.2 \%$, respectively as compared with that by thrombin (Fig. 6B).

\section{Discussion}

When platelet activation occurs, phospholipase C- $\gamma_{2}$ hydrolyzes $\mathrm{PIP}_{2}$ to $\mathrm{IP}_{3}$ and diacylglycerol (DG) on the platelet membrane. The resulting $\mathrm{IP}_{3}$ induces intracellular $\mathrm{Ca}^{2+}\left(\left[\mathrm{Ca}^{2+}\right]_{\mathrm{i}}\right)$ mobilization from the dense tubular system, and DG-dependent protein kinase $\mathrm{C}$ is activated through DG [16]. Increased $\left[\mathrm{Ca}^{2+}\right]_{\mathrm{i}}$ causes phosphorylation of $\mathrm{Ca}^{2+} /$ calmodulin dependent proteins myosin light chain $(20 \mathrm{kDa})$ and pleckstrin $(40$ or $47 \mathrm{kDa})$ resulting in platelet activation [17].

On the other hand, cyclic nucleotides is known to inhibit platelet aggregation by reducing $\left[\mathrm{Ca}^{2+}\right]_{\mathrm{i}}$ and activating cAMP- and cGMP-dependent protein kinase (PKA and PKG) [18]. In this study, scoparone significantly inhibited U46619-induced platelets aggregation without cytotoxicity (Fig. 1). In addition, scoparone increased cAMP and cGMP production in platelets in a concentrationdependent manner, and suppressed $\left[\mathrm{Ca}^{2+}\right]_{\mathrm{i}}$ concentrations. These results indicate that increased scoparone-induced cyclic nucleotides played a central role in inhibiting platelet activity by downregulating $\left[\mathrm{Ca}^{2+}\right]_{\mathrm{i}}$. Increased cAMP and cGMP can be used to phosphorylate multiple substrates by activating PKA and PKG, of which it is known to affect inositol 1, 4, 5-triphosphate receptor $\left(\mathrm{IP}_{3} \mathrm{R}\right)$ phosphorylation [7]. As shown in Fig. 3A, the phosphorylation of $\mathrm{IP}_{3} \mathrm{R}$ was increased in a concentration-dependent manner by scoparone. This suggests that scoparone inhibited $\left[\mathrm{Ca}^{2+}\right]_{\mathrm{i}}$ by inhibiting the opening of calcium channels in the dense tubular system through phosphorylation of $\mathrm{IP}_{3} \mathrm{R}$, which appears to be due to the activation of PKA and PKG. In addition, the increase of cAMP and cGMP production by scoparone resulted in the phosphorylation of VASP protein, a substrate through activation of PKA and PKG. VASP acts as a major substrate of cAMP/ cGMP-dependent PKA/PKG that regulates platelet activation by regulating platelet secretion and adhesion properties, and VASP phosphorylation is also known to inhibit activation of integrin $\alpha \mathrm{IIb} / \beta_{3}$ and consequently inhibit platelet aggregation $[19,20]$.

In this study, scoparone strongly inhibited fibrinogen binding to $\alpha \mathrm{IIb} / \beta_{3}$ in U46619-stimulated platelets. This is believed to be related to VASP Ser ${ }^{157}$ and VASP $\operatorname{Ser}^{239}$ phosphorylation due to increased cAMP and cGMP production by scoparone. In addition, Integrin $\alpha \mathrm{IIb} / \beta_{3}$-mediated signal transduction usually leads to deformation of the platelet cytoskeleton, which affects platelet proliferation and coagulation regression. Coagulation contraction is the most important step during repair of damaged parts of blood 

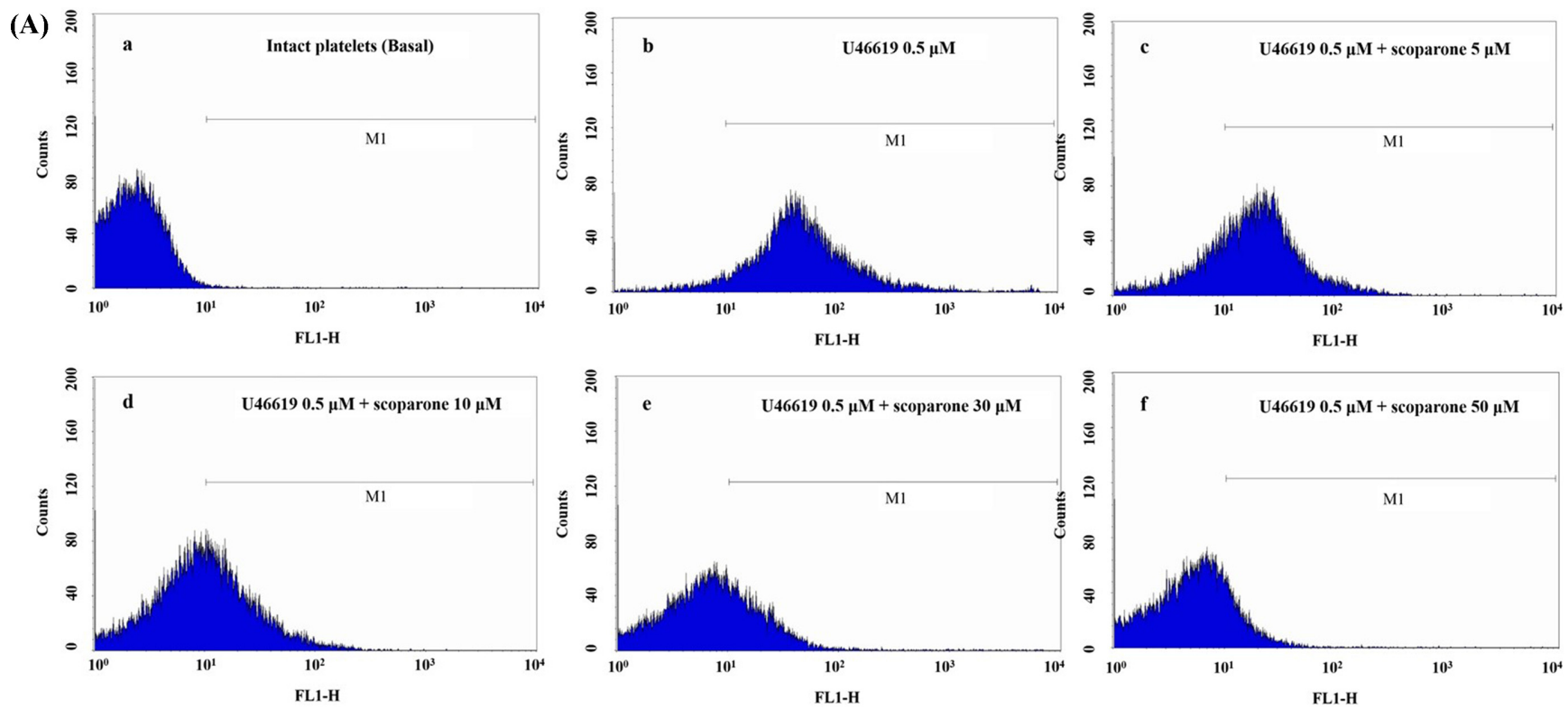

(B)

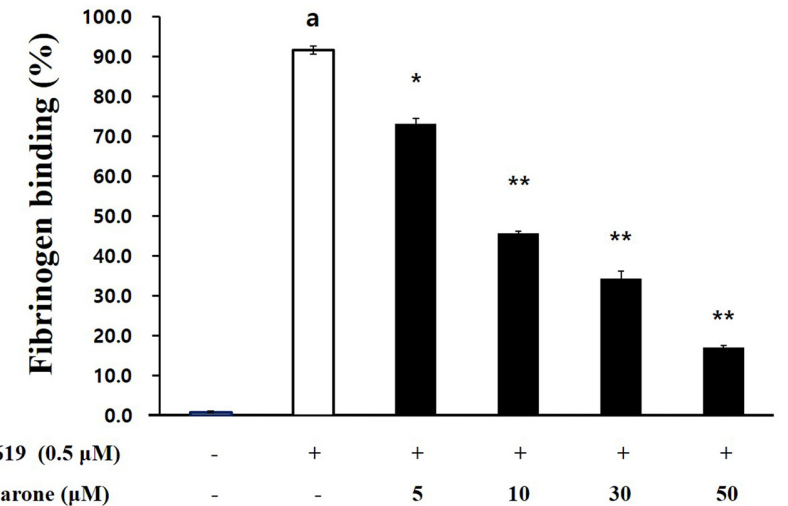

vessels. Damaged blood vessels accumulate activated platelets and develop into fibrin platelet meshwork. Solidification formation, sealing the damaged container, begins to shrink for a time of about 30 to $60 \mathrm{~min}$ and pulls the cutting edges together. The interaction between $\alpha \mathrm{IIb} / \beta_{3}$ and fibrin plays an important role in coagulation formation, and $\alpha \mathrm{IIb} / \beta_{3}$ inhibitors strongly inhibit coagulation contraction [21]. Thrombin causes coagulation and activates platelet $\alpha \mathrm{IIb} / \beta_{3}$, which increases the binding of fibrinogen to $\alpha \mathrm{IIb} /$ $\beta_{3}$, causing coagulation shrinkage. As shown in Fig. 6 , the antiplatelet effect of scoparone suppressed thrombin-induced fibrin coagulation, which is the actual result of thrombosis inhibition. These results suggest that scoparone has potential as a potent antiplatelet substance that increases cAMP and cGMP production and inhibits thrombogenesis.

Further research is needed on which mechanisms have increased the production of cAMP and cGMP. Some previous studies have reported that scoparone promotes penile erection through vasodilation by increasing nitric oxide and increasing cGMP
Fig. 5 Effects of scoparone on U46619-induced fibrinogen binding. (A) The flow cytometry histograms on fibrinogen binding. a, Intact platelets (base); b, U46619 (0.5 $\mathrm{MM})$; c, U46619 $(0.5 \mu \mathrm{M})+$ scoparone $(5 \mu \mathrm{M})$; d, $\mathrm{U} 46619(0.5 \mu \mathrm{M})+$ scoparone $(10 \mu \mathrm{M})$; e, U46619 $(0.5 \mu \mathrm{M})+$ scoparone $(30 \mu \mathrm{M})$; f, U46619 $(0.5 \mu \mathrm{M})+$ scoparone $(50 \mu \mathrm{M})$. (B) Effects of scoparone on U46619-induced fibrinogen binding (\%). Washed platelets $\left(10^{8}\right.$ cells $\left./ \mathrm{mL}\right)$ bound to Alexa Flour 488 -human fibrinogen $(30 \mu \mathrm{g} / \mathrm{mL})$ were stimulated with U46619 $(0.5 \mu \mathrm{M})$ after adding $2 \mathrm{mM} \mathrm{CaCl}$. Fibrinogen binding capacity was performed using a flow cytometer (BD Biosciences, San Jose, CA, USA) and analyzed by Cell-Quest software (BD Biosciences). The data are expressed as the mean \pm standard deviation $(\mathrm{n}=4) .{ }^{\mathrm{a}} p<0.05$ compared with no-stimulated platelets, ${ }^{*} p<0.05,{ }^{*} p<0.001$ compared with the U46619-stimulated platelets

production [22]. We also confirmed that scoparone strongly increased cGMP production, and this result could be attributed to the effect of NO. In addition, cAMP and cGMP rely on the activation of cyclic nucleotide PDE or adenylyl cyclase/guanyl cyclase [23]. Since cyclic nucleotide levels in platelet aggregation is increased through the inhibition of PDE activity, PDE inhibitors may have a therapeutic effect on thrombosis [24]. Indeed, PDE inhibitors such as triple rusal, cilostazol and dipyridamole are used as antiplatelets to clinically increase the production of cyclic nucleotides [6]. Scoparone may be developed as a drug with antiplatelet action under similar mechanism.

In conclusion, scoparone phosphorylated VASP and $\mathrm{IP}_{3} \mathrm{R}$ by increasing cAMP and cGMP in human platelets, inhibiting the activation of integrin $\alpha \mathrm{IIb} / \beta_{3}$ and the recruitment of $\mathrm{Ca}^{2+}$ into the cytoplasm. As a result, fibrin coagulation of thrombin induction was strongly inhibited. Therefore, this study suggests that scoparone can be developed as an effective antithrombotic and therapeutic agent. 
(A)

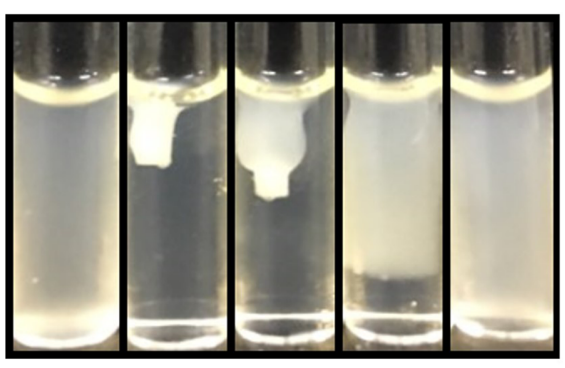

Thrombin $(0.05 \mathrm{U} / \mathrm{mL})$ Scoparone $(\mu \mathrm{M})$

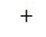

10
(B)

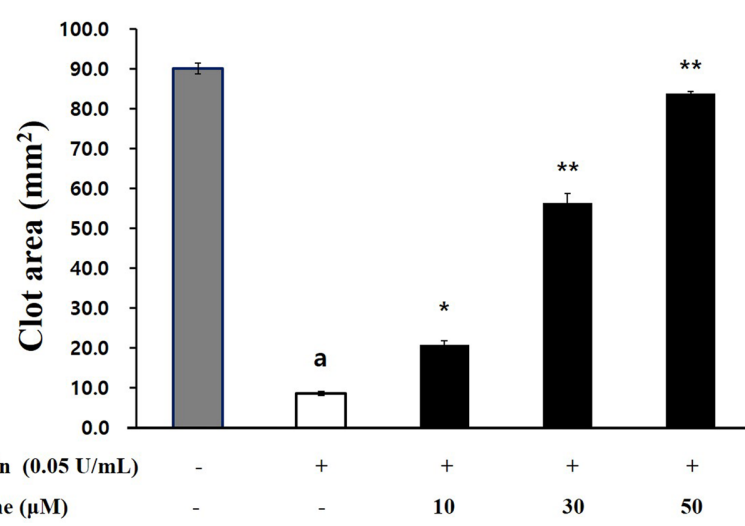

Scoparone $(\mu \mathrm{M})$

Fig. 6 Effects of scoparone on fibrin clot retraction. (A) Effects of scoparone on thrombin-retracted fibrin clot photographs (B) Effects of scoparone on thrombin-retracted fibrin clot area. Human PRP $(500 \mu \mathrm{L})$ was moved into a polyethylene tube to avoid adhesion, various scoparone $(10,30,50 \mu \mathrm{M})$ were preincubated with separate samples for $15 \mathrm{~min}$ at $37{ }^{\circ} \mathrm{C}$, using thrombin $(0.05 \mathrm{U} / \mathrm{mL})$ for stimulation. At $15 \mathrm{~min}$, pictures of fibrin clot were taken using a digital camera. The area of the clot was calculated using the Image J Software (v1.46, National Institutes of Health, USA). The data are expressed as the mean \pm standard deviation $(\mathrm{n}=4) .{ }^{\mathrm{a}} p<0.05$ compared with no-stimulated platelets, ${ }^{*} p<0.05$, $*_{*} p<0.001$ compared with the U46619-stimulated platelets

Acknowledgments Funding for this paper was provided by Namseoul University

Conflict of interest The authors declare no conflict of interest.

\section{References}

1. Furuichi T, Mikoshiba K (1995) Inositol 1, 4, 5-trisphosphate receptormediated $\mathrm{Ca}^{2+}$ signaling in the brain. J Neurochem 64: 953-960

2. Ohkubo S, Nakahata N, Ohizumi Y (1996) Thromboxane A2-mediated shape change: independent of Gq-phospholipase C--Ca ${ }^{2+}$ path- way in rabbit platelets. Br J Pharmacol 117: 1095-1104

3. Saitoh M, Naka M, Hidaka H (1986) The modulatory role of myosin light chain phosphorylation in human platelet activation. Biochem Biophys Res Commun 140: 280-287

4. Cattanco M, Tenconi PM, Lecchi A, Mannucci PM (1991) In vitro effects of picotamide on human platelet aggregation, the release reaction and thromboxane B2 production. Thromb Res 62: 717-724

5. Su CY, Shiao MS, Wang CT (1999) Differential effects of ganodermic

acid $\mathrm{S}$ on the thromboxane A2-signaling pathways in human platelets. Biochem Pharmacol 58: 587-595

6. Menshikov MYU, Ivanova K, Schaefer M, Drummer C, Gerzer R (1993) Influence of the cGMP analog 8-PCPT-cGMP on agonist-induced increases in cytosolic ionized $\mathrm{Ca}^{2+}$ and on aggregation of human platelets. Eur J Pharmacol 245: 281-284

7. Schwarz UR, Walter U, Eigenthaler M (2001) Taming platelets with cyclic nucleotides. Biochem Pharmacol 62: 1153-1161

8. Cavallini L, Coassin M, Borean A, Alexandre A (1996) Prostacyclin and sodium nitroprusside inhibit the activity of the platelet inositol 1,4,5trisphosphate receptor and promote its phosphorylation. $J$ Biol Chem 271: 5545-5551

9. Quinton TM, Dean WL (1992) Cyclic AMP-dependent phosphorylation of the inositol-1,4,5-trisphosphate receptor inhibits $\mathrm{Ca} 2+$ release from platelet membranes. Biochemical and Biochem Biophys Res Commun 184: 893-899

10. Laurent V, Loisel TP, Harbeck B, Wehman A, Gröbe L, Jockusch BM, Wehland J, Gertler FB, Carlier MF (1999) Role of proteins of the Ena/ VASP family in actin-based motility of Listeria monocytogenes. J Cell Biol 144: 1245-1258

11. Sudo T, Ito H, Kimura Y (2003) Phosphorylation of the vasodilatorstimulated phosphoprotein (VASP) by the anti-platelet drug, cilostazol, in platelets. Platelets 14: $381-390$

12. Huang HC, Chu SH, Chao PD (1991) Vasorelaxants from Chinese herbs, emodin and scoparone, possess immunosuppressive properties. European Journal of Pharmacology 198: 211-213

13. Huang HC, Lee CR, Weng YI, Lee MC, Lee YT (1992) Vasodilator effect of scoparone (6,7-dimethoxycoumarin) from a Chinese herb. European Journal of Pharmacology 218: 123-128

14. Shin JH, Kwon HW, Lee DH (2019) Ginsenoside F4 inhibits platelet aggregation and thrombus formation by dephosphorylation of IP3RI and VASP. J Appl Biol Chem 62: 93-100

15. Grynkiewicz G, Poenie M, Tsien RY (1985) A new generation of $\mathrm{Ca}^{2+}$ indicators with greatly improved fluorescence properties. J Biol Chem 260: 3440-3450

16. Berridge MJ, Irvine RF (1989) Inositol phosphates and cell signalling. Nature 341: 197-205

17. Nishikawa M, Tanaka T, Hidaka H (1980) $\mathrm{Ca}^{2+}$-calmodulin-dependent phosphorylation and platelet secretion. Nature 287: 863-865

18. Kuo JF, Andersson RG, Wise BC, Mackerlova L, Salomonsson I, Brackett NL, Katoh N, Shoji M, Wrenn RW (1980) Calcium-dependent protein kinase: widespread occurrence in various tissues and phyla of the animal kingdom and comparison of effects of phospholipid, calmodulin, and trifluoperazine. Proc Natl Acad Sci 77: 7039-7043

19. Wangorsch G, Butt E, Mark R, Hubertus K, Geiger J, Dandekar T, Dittrich M (2011) Time-resolved in silico modeling of finetuned cAMP signaling in platelets: feedback loops, titrated phosphorylations and pharmacological modulation, BMC Syst Biol 5: 178

20. Napeñas J, Oost FC, DeGroot A, Loven B, Hong CH, Brennan MT, Lockhart PB, van Diermen DE (2013) Review of postoperative bleeding risk in dental patients on antiplatelet therapy. Oral Surg Oral Med Oral Pathol Oral Radiol 115: 491-499

21. Topol EJ, Byzova TV, Plow EF (1999) Platelet GPIIb-IIIa blockers. The Lancet 353: 227-231

22. Choi BR, Kim HK, Park JK (2017) Penile Erection Induced by Scoparone from Artemisia capillaris through the Nitric Oxide-Cyclic Guanosine Monophosphate Signaling Pathway. World J Mens Health 35: 196-204

23. Gao J, Tao J, Liang W, Zhao M, Du X, Cui S, Duan H, Kan B, Su X, Jiang Z (2015) Identification and characterization of phosphodiesterases that specifically degrade 3'3'-cyclic GMP-AMP. Cell Res 25: $539-550$

24. Haslam RJ, Dickinson NT, Jang EK (1999) Cyclic nucleotides and phosphodiesterases in platelets. Thromb Haemost 82: $412-423$ 